\title{
Palmitic acid induces endoplasmic reticulum stress in AML12 liver cells
}

\author{
Palmitik asit AML12 karaciğer hücrelerinde endoplazmik retikulum stresi uyarır
}

Tugce DEMIREL, Saime BATIREL

\begin{abstract}
Objectives: Non-alcoholic fatty liver disease (NAFLD) is characterized by increased fatty acid levels in serum and liver. The mechanism of NAFLD is unclear. The role of endoplasmic reticulum (ER) stress attracts attention. First aim of this study was to design an in vitro NAFLD model. The effects of palmitic acid (PA) alone or combination with oleic acid (OA) on intracellular reactive oxygen species (ROS) production and ER stress in liver cells were investigated as a second aim.

Materials and Methods: AML12 cells were exposed to PA and/or OA with different concentrations and combinations. Intracellular lipids and cell viability were detected with Oil red $\mathrm{O}$ staining and WST-1 assay respectively. Intracellular ROS accumulation was measured by flow cytometry analysis. Expression of ER stress proteins, immunoglobulin binding protein (BiP) and IRE1, were evaluated with western blot analysis.

Results: Intracellular lipid content was increased in all treated groups. Cell viability was decreased whereas ROS generation and expression of the ER stress proteins were increased in cells treated with PA. However, these effects were not observed in the cells treated with $\mathrm{OA}+\mathrm{PA}$ combination.

Conclusion: PA induces ROS generation and the ER stress pathway that is mediated by IRE1 in liver cells. Addition of OA enhances these effects.
\end{abstract}

Keywords: Non-alcoholic fatty liver disease, Palmitic acid, Oleic acid, Endoplasmic reticulum stress

\footnotetext{
Tugce Demirel

Department of Medical Biochemistry, School of Medicine, Marmara University, Maltepe, Istanbul, Turkey

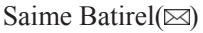

GEMHAM and Department of Medical Biochemistry, School of Medicine, Marmara University, Maltepe, Istanbul, Turkey

e-mail:saime.batirel@marmara.edu.tr
}

Submitted / Gönderilme: 18.11.2017

Accepted/Kabul: 21.12 .2018
ÖZ

Amaçlar: Nonalkolik yağlı karaciğer hastalığı (NAYKH), serum ve karaciğerde artmış yağ asit seviyeleri ile karakterizedir. NAYKH'nin mekanizması net değildir. Endoplazmik retikulum (ER) stresin rolü, dikkat çekmektedir. Bu çalışmanın ilk amacı, bir in vitro NAYKH modeli dizayn etmektir. İkinci hedef olarak, palmitik asit (PA)'in yalnız veya oleik asit (OA) ile kombinasyonu, karaciğer hücrelerinde, reaktif oksijen türleri (ROT) oluşumu ve ER stresi üzerindeki etkileri araştırıldı.

Gereçler ve Yöntemler: AML12 hücreleri, farklı konsantrasyon ve kombinasyonlarda, OA ve PA ile muamele edildi. Hücre içi lipidler ve hücre canlılığı, sırasıyla Oil red O boyaması ve WST-1 analiziyle saptand. Hücre içi ROT birikimi, akış sitometrisi ile ölçüldü. ER stres proteinleri, immunoglobulin bağlayıcı protein (BiP) ve IRE1, western blot analizi ile değerlendirildi.

Bulgular: Hücre içi lipit içeriği, tüm uygulamlara maruz kalmış gruplarda arttı. PA ile muamele edilmiş hücrelerde, hücre canlılığı azald 1 ve ROT üretimi ve ER stres proteinlerin ekspresyonu arttı. Ancak, bu etkiler OA+PA kombinasyonu ile muamele edilmiş hücrelerde gözlenmedi.

Sonuç: PA, karaciğer hücrelerinde, ROS üretimini ve IRE1 aracılı ER stres yolağını indükler. Ama OA eklenmesi bu etkileri iyileştirir.

Anahtar kelimeler: Nonalkolik yağlı karaciğer hastalığı, Palmitik asit, Oleik asit, Endoplazmik retikulum stres

\section{Introduction}

Free fatty acid (FFA) concentrations in plasma determine the metabolic health. Increased levels of FFAs in plasma were observed in abnormal metabolic conditions such as insulin resistance, type 2 diabetes, obesity and nonalcoholic fatty liver disease (NAFLD) [1]. Liver is the main organ that regulates the metabolism of FFAs where they are taken up from blood, and then esterified into neutral triglycerides.

Non-alcoholic fatty liver disease is a disease with increasing prevalence, which is characterized by an accumulation of lipids in the liver without excessive alcohol 
consumption. It affects $6-45 \%$ of the general population and leads to cirrhosis and hepatocellular carcinoma [2]. It represents a spectrum of disease ranging from simple hepatic steatosis to non-alcoholic steatohepatitis (NASH). While the former is a benign, the latter is characterized by increased inflammation and apoptosis in addition to steatosis [3].

The exact molecular mechanism of NAFLD remains unclear. A number of studies indicate the potential role of endoplasmic reticulum (ER) stress in the development of NAFLD [4,5]. Convenient and accurate in vitro models are needed to clarify the mechanism of NAFLD and to find effective therapeutic strategies. These models will allow us to study the molecular mechanisms of NAFLD by controlling the cellular environment. Since, major FFAs in serum of obese patients are palmitic (C16:0 - PA) and oleic (18:1 $\omega-9$ - OA) acids [6], previous in vitro models were generated by overloading hepatocytes with FFAs. However, the data from these models were contradictory [7-12].

In this study, our first aim was to design an in vitro model which has characteristics of NAFLD. Accordingly, AML12 cells were exposed to PA and/or OA for $24 \mathrm{~h}$ and steatogenic and cytotoxic effects of the treatments were determined. The effects of PA alone or in combination with OA on intracellular reactive oxygen species (ROS) production and ER stress in AML12 liver cells were investigated as a second aim.

\section{Materials and Methods}

\section{Materials}

AML12 mouse liver hepatocyte cell line was obtained from American Tissue Culture Collection (VA, USA). Dulbeco's modified eagle's medium (DMEM)/F12 medium, fetal bovine serum (FBS), trypsin-EDTA, and penicillinstreptomycin were purchased from PAN Biotech $(\mathrm{GmbH}$, Aidenbach Germany). Dexamethasone, palmitic acid sodium salt (Na-PA), oleic acid sodium salt (Na-OA) and fatty acids-free bovine serum albumin (BSA) were obtained from Sigma (St. Louis, MO, USA). Insulin-Transferrin-Selenium (ITS) was provided from GIBCO Life Technologies Ltd (Grand Island, NY, USA). Ethical approval for this study was obtained from Marmara University, School of Medicine Ethical Committee.

\section{Cell Culture}

AML12 cells were cultured in DMEM/F12 medium supplemented with $1 \%$ penicillin/ streptomycin, 10\% FBS,
$20 \mu \mathrm{g} / \mathrm{ml}$ dexamethasone and $0.9 \%$ ITS at $37^{\circ} \mathrm{C}$ humidified air with $5 \% \mathrm{CO}_{2}$.

\section{Preparation of $\mathrm{Na}-\mathrm{PA}$ and $\mathrm{Na}-\mathrm{OA}$ solutions and treatment}

$\mathrm{Na}-\mathrm{PA}$ and $\mathrm{Na}-\mathrm{OA}$ were dissolved in $99 \%$ ethanol to prepare $200 \mathrm{mM}$ stock solutions. The stock solutions of $\mathrm{Na}-\mathrm{PA}$ and $\mathrm{Na}-\mathrm{OA}$ were then complexed with $5 \%$ bovine serum albumin (BSA) solution at $37^{\circ} \mathrm{C}$ to achieve $4 \mathrm{mM}$ solutions of Na-PA and Na-OA. Na-PA and Na-OA were further diluted to obtain the desired final concentrations.

AML12 cells were exposed to Na-PA and/or Na-OA with different concentrations and combinations. The cells were treated with $0.333 \mathrm{mM} \mathrm{Na}-\mathrm{PA}$ or $0.666 \mathrm{mM} \mathrm{Na}-\mathrm{PA}$ or $0.333 \mathrm{mM} \mathrm{Na-OA}$ or $0.666 \mathrm{mM} \mathrm{Na-OA}$ or $0.333 \mathrm{mM}$ $\mathrm{Na}-\mathrm{PA}+0.333 \mathrm{mM} \mathrm{Na}-\mathrm{OA}$ or $0.333 \mathrm{mM} \mathrm{Na}-\mathrm{PA}+0.666$ $\mathrm{mM} \mathrm{Na}-\mathrm{OA}$ for $24 \mathrm{~h}$. BSA supplemented medium was used as a control in all experiments. Cells were serum starved for 24 hours before treatment. After treatment, the cells were collected for the required assays.

\section{Detection of intracellular lipid droplets}

In order to determine intracellular neutral lipid, the cells were stained with Oil red O (Bio-optica, Milano, Italy). Briefly, they were seeded into 96 well cell culture plates and treated with Na-PA and/or Na-OA for $24 \mathrm{~h}$ as described above. Treated cells were washed with phosphate buffer solution (PBS), and fixed with 3\% paraformaldehyde. Neutral lipids were stained with Oil Red $\mathrm{O}$ and the nuclei were counterstained with hematoxylin. After washing with PBS, the cells were visualized using light microscopy (Carl Zeiss, Jena, Germany).

\section{Cell viability assay}

The effect of FFAs on cell viability was determined using WST-1 Cell Proliferation Assay kit (Roche, Mannheim, Germany). Cells $\left(5 \times 10^{3}\right)$ were plated into each well of a 96well culture plate and treated with Na-PA and/or Na-OA for $24 \mathrm{~h}$ as described above. After treatment they were incubated with $10 \%$ WST-1 reagent. The absorbance of formazan compounds was measured at $440 \mathrm{~nm}$ using a 96-well plate reader (Molecular Devices, CA, USA). Cell viabilities of treated cells were expressed as percentage of cell viabilities of control cells. 


\section{Measurement of intracellular ROS production}

Intracellular ROS production was measured with radicalsensitive H2DCFDA dye using flow cytometry. The cells were seeded into 12 -well culture plates at $6.1 \times 10^{4}$ cells per well. After treatment with $0.333 \mathrm{mM} \mathrm{Na}-\mathrm{PA}$ or $0.333 \mathrm{mM} \mathrm{Na}-\mathrm{PA}$ plus $0.666 \mathrm{mM} \mathrm{Na-OA}$, the cells were washed with PBS and then incubated with $\mathrm{H} 2 \mathrm{DCFDA}$ for $45 \mathrm{~min}$ at $37^{\circ} \mathrm{C}$ in the dark. Levels of oxidized dye were detected using a flow cytometry (FACSCalibur). The collected data from 10.000 cells were analyzed with CellQuest software (BD Biosciences, San Jose, CA). The data was expressed as $\%$ of control.

\section{Western Blot}

AML12 cells were treated with $0.333 \mathrm{mM} \mathrm{Na-PA}$ or 0.333 $\mathrm{mM}$ Na-PA plus $0.666 \mathrm{mM}$ Na-OA. Treated cells were lysed in radioimmunoprecipitation assay (RIPA) buffer (Cell signaling, Leiden, Netherlands), which contains protease and phosphatase inhibitors. Whole-cell lysates were collected and centrifuged. Supernatants were transferred to fresh tubes. Protein concentrations in the supernatant were measured with Bradford assay. Equal amounts of proteins were separated by $10 \%$ sodium dodecyl sulphate polyacrylamide gel electrophoresis (SDS-PAGE) and transferred into nitrocellulose membranes (Bio-Rad Laboratories, Hercules, CA). The membranes were blocked with $5 \%$ fatty acidfree BSA in $0.5 \%$ Triton X-100-TBS (TBST) and then immunoblotted with primary antibodies against IRE1 (abcam, MA, USA) and BiP (Cell Signaling, MA, USA) overnight. The next day, they were washed with tris-buffered saline with Tween (TBST) and incubated with horseradish peroxidase (HRP)-conjugated secondary antibodies for $2 \mathrm{~h}$. Protein bands were visualized with a chemiluminescent substrate (Thermo Fisher Scientific, IL, USA) using ChemiDoc Imaging system (Bio-Rad Laboratories, Hercules, CA). The density of bands was quantified using Image Lab Software (Bio-Rad Laboratories, Hercules, CA). Actin (Novus Biologicals, CO, USA) was used as an internal control and the expressions of target proteins were normalized to the levels of $\beta$-actin.

\section{Statistical Analysis}

The data were represented as means \pm standard deviation (SD). Statistical significances were analyzed using SPSS software (version 13.0, SPSS, Chicago, IL, USA). One-way analysis of variance (ANOVA) followed by Bonferroni post hoc test was used to compare the differences in more than two groups. $P<$ 0.005 value was considered statistically significant.

\section{Results}

\section{The exposure to $\mathrm{Na}-\mathrm{PA}$ and $\mathrm{Na}-\mathrm{OA}$ increases lipid levels in AML12 cells differentially}

Since increased lipid level in hepatocyte is a characteristic feature of NAFLD, we confirmed it with Oil red O staining. As shown in Figure 1, in all treatment groups, lipid content was increased in comparison to control group. However, there was a clear higher lipid accumulation in Na-OA treated groups than in just Na-PA treated groups.

(A)

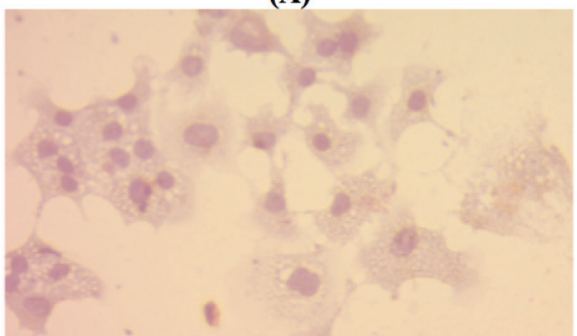

(B)

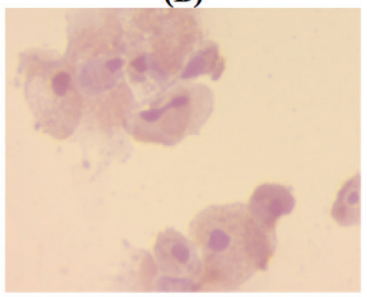

(D)

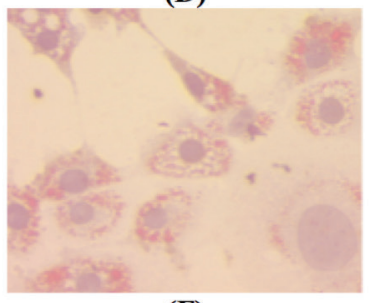

(F)

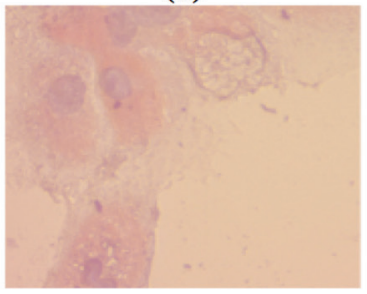

(C)

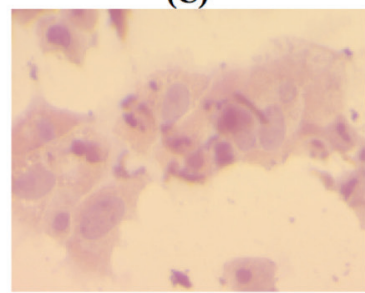

(E)

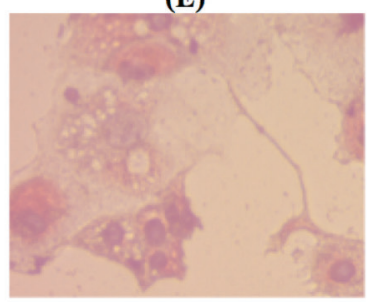

(G)

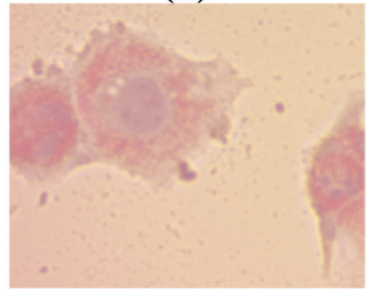

Figure 1. Effect of Na-PA and Na-OA on lipid accumulation in AML12 cells. Intracellular lipid is stained with Oil Red $\mathrm{O}$ after the cells exposed to $\mathrm{Na}-\mathrm{PA}$ and/or Na-OA with different concentrations and combinations for 24h. Nuclei were stained with hematoxylin. Representative pictures of cells were taken by a microscope at $40 \mathrm{x}$ original magnification. (A) Control cells treated with BSA only; (B) Cells treated with $0.333 \mathrm{mM} \mathrm{PA}$; (C) Cells treated with $0.666 \mathrm{mM} \mathrm{PA}$; (D) Cells treated with $0.333 \mathrm{mM} \mathrm{OA}$; (E) Cells treated with $0.666 \mathrm{mM} \mathrm{OA}$; (F) Cells treated with $0.333 \mathrm{mM} \mathrm{PA}+0.333 \mathrm{mM}$ OA; (G) Cells treated with $0.333 \mathrm{mM} \mathrm{PA}+0.666 \mathrm{mM}$ OA. (PA, palmitic acid sodium salt; OA, oleic acid sodium salt) 


\section{Cell viability of AML12 cells is reduced by Na-PA but not by $\mathrm{Na}-\mathrm{OA}$}

We observed that addition of Na-OA did not affect the cell viability measured with WST-1 assay even at high doses, while Na-PA significantly decreased the cell viability in a dose-dependent manner $(P<0.05)$ (Figure 2$)$. Addition of $\mathrm{Na}-\mathrm{OA}$ at two different concentrations into $0.333 \mathrm{mM} \mathrm{Na}-\mathrm{PA}$ enhanced viabilities of the cells. Combined treatments with $\mathrm{Na}-\mathrm{PA}$ and $\mathrm{Na}-\mathrm{OA}$ reduced cell viability by $8 \%$ and $14 \%$ respectively but the reductions were not statistically significant.

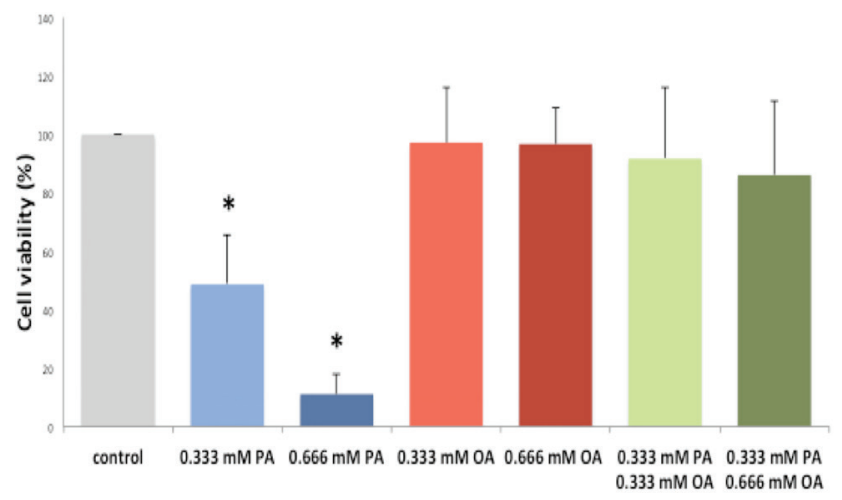

Figure 2. Effect of Na-PA and Na-OA on cell viability of AML12 cells. The cells were exposed to Na-PA or Na-OA with different concentrations and combinations of them for $24 \mathrm{~h}$. Viabilities of the cells were measured with WST-1 assay. Data are presented as the mean \pm S.D. $* P<0.05$ compared with control. (PA, palmitic acid sodium salt; OA, oleic acid sodium salt)

\section{Intracellular ROS generation was increased by $\mathrm{Na}-\mathrm{PA}$}

The above mentioned data showed us that we could design an in vitro NAFLD model in our laboratory. Since we aimed to clarify the molecular mechanism of NAFLD, we examined the effect of PA or PA plus OA on ROS generation in AML12 cells using this model. Treatment of cells with Na-PA alone at a concentration of 0.333 $\mathrm{mM}$ increased ROS level in the cells by $162 \%$ when compared with control $(P<0.05)$. On the other hand, the combination treatment with $0.333 \mathrm{mM} \mathrm{Na}-\mathrm{PA}$ and 0.666 $\mathrm{mM}$ Na-OA increased the ROS generation in the cells by $125 \%$. But there was no significant difference between control group and $0.333 \mathrm{mM} \mathrm{Na}-\mathrm{PA}+0.666 \mathrm{mM} \mathrm{Na}-\mathrm{OA}$ $\mathrm{mM}$ treated group (Figure 3).

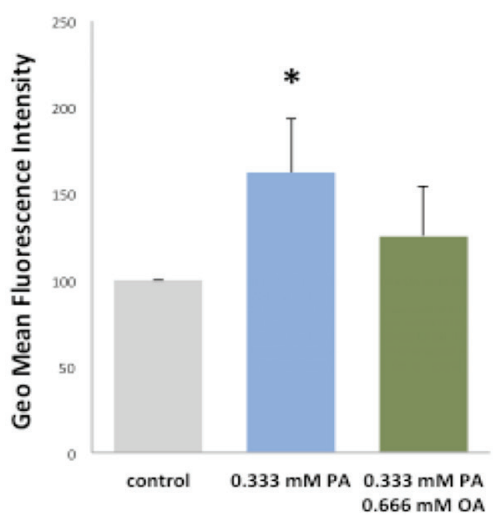

Figure 3. Effect of Na-PA and Na-OA on ROS production in AML12 cells. ROS production in the cells were measured with H2DCFDA using flow cytometry after treatment with $0.333 \mathrm{mM} \mathrm{Na}-\mathrm{PA}$ or $0.333 \mathrm{mM} \mathrm{Na}-\mathrm{PA}+0.666$ $\mathrm{mM} \mathrm{Na}-\mathrm{OA}$ for $24 \mathrm{~h}$. Data are presented as the mean \pm S.D. $* P<0.05$ compared with control. (PA, palmitic acid sodium salt; OA, oleic acid sodium salt)

\section{ER stress is induced by $\mathrm{Na}-\mathrm{PA}$ but addition of $\mathrm{Na}-\mathrm{OA}$ enhances it}

Because NAFLD is associated with ER stress, we measured expression of BiP (GRP78) which is ER chaperone protein, and IRE1, unfolded protein response (UPR) sensor protein, in the cells after treatment with $0.333 \mathrm{mM} \mathrm{Na}-\mathrm{PA}$ alone or combined with $0.666 \mathrm{mM} \mathrm{Na}-\mathrm{OA}$. We observed that exposure of AML12 cells to $0.333 \mathrm{mM}$ Na-PA alone stimulated expression of BiP and IRE1, $(P<0.05$ vs control). On the other hand, the expression of these ER stress proteins were not changed by the combination treatment with $0.333 \mathrm{mM} \mathrm{Na}-\mathrm{PA}$ and $0.666 \mathrm{mM} \mathrm{Na}-\mathrm{OA}$ (Figure 4).
(A)

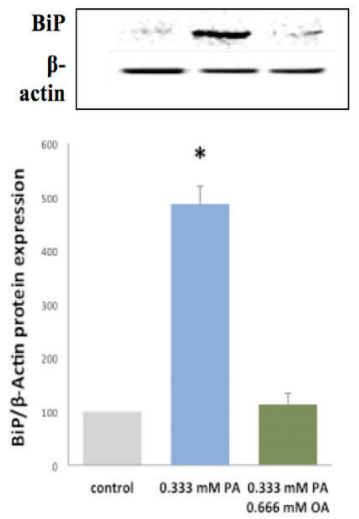

(B)

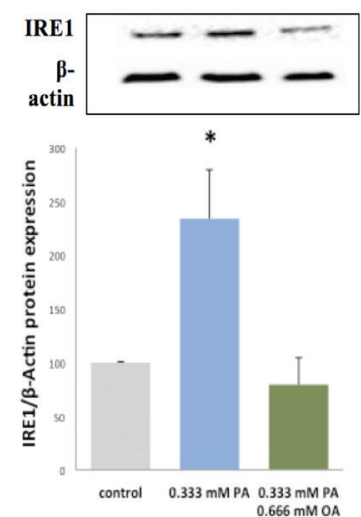

Figure 4. Effects of Na-PA and NA-OA on protein expressions of ER stress markers by AML12 cells.

Western blot analysis of (A) BiP and (B) IRE1 protein expression in the cells. Protein levels were normalized to $\beta$-actin. Data are presented as the mean \pm S.D. $* P<0.05$ compared with control. (IRE1, inositol-requiring enzyme $1, \mathrm{BiP}$, binding immunoglobulin protein; PA, palmitic acid sodium salt; $\mathrm{OA}$, oleic acid sodium salt) 


\section{Discussion}

Non-alcoholic fatty liver disease, is a common disease associated with obesity and diabetes. It is characterized by lipid accumulation in hepatocyte, which results from increased serum FFA levels in patients with NAFLD. There is a wide spectrum in NAFLD ranging from benign simple steatosis to non-alcoholic steatohepatitis (NASH). NASH is characterized with inflammation, oxidative stress and hepatic insulin resistance in addition to steatosis. It leads to development of end stage liver disease such as cirrhosis and hepatocellular carcinoma [2].

In vitro models of NAFLD have been established in order to understand the molecular mechanism of NAFLD. However, the results from previous studies varied, which might be caused by different exposure times and concentrations of FFAs, liver cell type and the amount of albumin in culture medium $[11,13]$. In the current study, our first aim was to design a convenient and accurate in vitro model, which mimics NAFLD in order to study its pathogenesis.

The liver cells used for in vitro models in previous studies varied from non tumoral (HuH7, L02, AML12, WRL68) $[7,10,11]$ to tumoral (HepG2, H4IIEC3, HuH7) cell lines $[7-10,12]$. Because primary culture of hepatocytes has technical and ethical limitations, commercial cell lines are found more suitable for in vitro models. We chose AML12 cells for our model because they display morphological and gene expression patterns characteristic of differentiated hepatocytes [14].

In previous studies in vitro models for NAFLD were based on overloading FFAs to hepatocytes at different concentrations and combinations. Because circulating FFAs in NAFLD is abundant in PA and OA [6], many outcomes were obtained from in vitro NAFLD models, through modulating the concentration and composition of PA and OA in culture medium [7-12].

We treated AML12 cells with different concentrations and combinations of PA and/or OA and then measured cell viability and lipid accumulation in the cells. Consistent with previous studies [7, 13], we found that both OA and PA caused a dosedependent intracellular lipid accumulation in AML12 cells in a dose dependent manner. OA was more steatogenic than PA when used at equimolar concentrations. It was assumed that this more steatogenic effect of $\mathrm{OA}$ resulted from readily incorporation of OA into triglycerides which is a defense mechanism against the toxicity of excess FFAs [7]. Additionally, we observed that there was no significant cytotoxicity in the groups treated with
OA, while PA decreased the cell viability in a dose dependent manner at equal concentrations. These data were in agreement with the results of other studies using other types of liver cells [7, 13]. The results in PA treated groups were matching with NASH symptoms, which included lipid accumulation and necrosis in the liver. Similar to other studies [7], we also showed that the exposure of cells to the mixture of OA and PA developed steatosis with low toxicity, which appeared similar to subjects with simple steatosis. Our data proved that $\mathrm{Na}-\mathrm{OA}$ was more tolerated by AML12 cells and rescued them from PA-induced lipotoxicity.

In the light of these data, we chose the $0.333 \mathrm{mM}$ PA treated group and $0.333 \mathrm{mM}$ PA plus $0.666 \mathrm{mM} \mathrm{OA}$ treated group which represented general properties of NAFLD at different stages, for subsequent assays. Using these in vitro cell models we were able to investigate the molecular mechanism of lipotoxicity on AML12 cells.

Oxidative stress is increased in NAFLD patients, who have higher ROS levels, lipid peroxidation products and lower antioxidant enzyme levels than healthy subjects [15]. It is known that increased PA levels induce ROS accumulation in liver, which initiates apoptosis and lead to acute lipotoxicity $[12,16]$. In agreement with these studies we observed increased ROS production in the cells treated with $0.333 \mathrm{mM}$ $\mathrm{PA}$ alone. However, addition of $\mathrm{Na}-\mathrm{OA}$ at a concentration of $0.666 \mathrm{mM}$ into culture medium prevented cells against formation of ROS. It was thought that addition of OA prevents PA incorporation into cellular phospholipids, which might play a role in attenuation of ROS production [16].

Meanwhile, endoplasmic reticulum (ER) stress is also induced by increased FFAs in hepatocytes of NAFLD patients [17]. ER stress initiates unfolded protein response (UPR), which can restore ER homeostasis. But if ER stress cannot be resolved it leads to cell death [18].

Unfolded protein response is activated by three main pathways [15]. Each of these pathways is mediated by a trans-membrane receptor in ER: (1) RNA-dependent protein kinase-like ER, eukaryotic initiation factor- $2 \alpha$ kinase (PERK), (2) inositol-requiring enzyme $1 \alpha$ (IRE1 $\alpha$ ), (3) activating transcription factor 6 (ATF6).

In resting conditions, these trans-membrane receptors are in inactive form, which are associated with binding immunoglobulin protein (BiP, also known as GRP78). Under ER stress, BiP dissociates from these three receptors, and subsequently IRE1 $\alpha$ and PERK is autophosphorylated or ATF6 is translocated [15]. 
In a previous study, BiP mRNA levels in HepG2 cells decreased after treatment with $0.450 \mathrm{mM}$ PA while they were not changed after treatment with $\mathrm{OA}$ at the same concentration [19]. It was also shown that over-expression of BiP attenuated PA-induced ER stress and hepatic triglyceride content $[19,20]$. However, in another study BiP expression was up-regulated in L02 and HepG2 liver cells treated with $0.108 \mathrm{mM}$ PA [10]. In our study, we showed that $0.333 \mathrm{mM}$ PA up-regulated BiP expression in AML12 cells. On the other hand, addition of Na-OA decreased this expression to normal levels.

One of the possible ER stress pathway mediated by palimitic acid is PERK/ATF4/CHOP pathway. Upregulation of phosphorylated PERK, ATF4 and CHOP was demonstrated after PA treatment in L02 and HepG2 liver cells [10]. On the other hand, in the same study, the other ER stress pathways, mediated by ATF6 and IRE1 did not seem to be a target for PA [10]. IRE1 has an endoribonuclease activity that removes an intron from the XBP1 mRNA, previously induced by ATF6 [21]. This spliced XBP-1 induces the transcription of molecular chaperons and genes involved in ER biogenesis. Inadequate hepatic XBP-1 protein expression was linked to NASH [4].

IRE1 was identified as a key regulator to prevent hepatic steatosis. It regulates lipogenesis by down-regulation of $\mathrm{C} /$ $\mathrm{EBP} \beta, \mathrm{C} / \mathrm{EBP} \delta, \operatorname{PPAR} \gamma$, and key enzymes for triglyceride biosynthesis under conditions of ER stress. Hepatocytespecific deletion of IRE1 causes hepatic steatosis [22].

In the current study, we observed that $0.333 \mathrm{mM}$ PA treatment increased expression of IRE1. Interestingly addition of $0.666 \mathrm{mM} \mathrm{OA}$ into the treatment caused lower expression than that in $0.333 \mathrm{mM}$ PA treated cells. These results suggested that $\mathrm{PA}$ induces ER stress through $\mathrm{BiP} /$ IRE1 pathway but existing of OA prevents the lipotoxicity induced by PA.

The main limitation of our study seems to be its cell culture design. Hepatocytes have autocrine and paracrine relationships with other cells, which affect metabolic pathways in the liver. However, this model provides us the ability to change and regulate the cellular environment.

\section{Conclusion}

In this study, using an in vitro NAFLD model, we found that the ER stress pathway that is mediated by IRE1 is induced by PA in the liver cells.

\section{Acknowledgments}

The authors have declared no conflict of interest. We thank Betul Gungordu for her technical assistance.

\section{References}

1. Ibrahim SH, Kohli R, Gores GJ. Mechanisms of lipotoxicity in NAFLD and clinical implications. J Pediatr Gastroenterol Nutr 2011;53:131-40. doi: 10.1097/ MPG.0b013e31822578db.

2. Polyzos SA, Kountouras J, Mantzoros CS. Adipose tissue, obesity and non-alcoholic fatty liver disease. Minerva Endocrinol 2017;42:92-108. doi: 10.23736/S03911977.16.02563-3.

3. Liu W, Baker RD, Bhatia T, et al. Pathogenesis of nonalcoholic steatohepatitis. Cell Mol Life Sci 2016;73:1969-87. doi: 10.1007/s00018-016-2161-x.

4. Bozaykut P, Sahin A, Karademir B, et al. Endoplasmic reticulum stress related molecular mechanisms in nonalcoholic steatohepatitis. Mech Ageing Dev 2016;157:1729. doi: 10.1016/j.mad.2016.07.001.

5. Guo B, Li Z. Endoplasmic reticulum stress in hepatic steatosis and inflammatory bowel diseases. Front Genet 2014;5:242. doi: 10.3389/fgene.2014.00242.

6. Gambino R, Bugianesi E, Rosso C, et al. Different serum free fatty acid profiles in NAFLD subjects and healthy controls after oral fat load. Int J Mol Sci 2016;17:479. doi: 10.3390/ ijms 17040479.

7. Ricchi M, Odoardi MR, Carulli L, et al. Differential effect of oleic and palmitic acid on lipid accumulation and apoptosis in cultured hepatocytes. J Gastroenterol Hepatol 2009;24:83040. doi: 10.1111/j.1440-1746.2008.05733.x.

8. Cui W, Chen SL, Hu KQ. Quantification and mechanisms of oleic acid-induced steatosis in HepG2 cells. Am J Transl Res 2010;1;2:95-104.

9. Gao D, Nong S, Huang X, et al. The effects of palmitate on hepatic insulin resistance are mediated by NADPH Oxidase 3-derived reactive oxygen species through JNK and p38MAPK pathways. J Biol Chem 2010;285:29965-73. doi: 10.1074/jbc.M110.128694.

10. Cao J, Dai DL, Yao L, et al. Saturated fatty acid induction of endoplasmic reticulum stress and apoptosis in human liver cells via the PERK/ATF4/CHOP signaling pathway. Mol Cell Biochem 2012;364:115-29. doi: 10.1007/s11010-0111211-9.

11. Chavez-Tapia NC, Rosso N, Tiribelli C. Effect of intracellular lipid accumulation in a new model of non-alcoholic fatty liver disease. BMC Gastroenterol 2012;12:20. doi: 10.1186/1471230X-12-20.

12. Egnatchik RA, LeamyAK, Noguchi Y, etal. Palmitate-induced activation of mitochondrial metabolism promotes oxidative stress and apoptosis in H4IIEC3 rat hepatocytes. Metabolism 2014;63:283-95. doi: 10.1016/j.metabol.2013.10.009. 
13. Oh JM, Choi JM, Lee JY, et al. Effects of palmitic acid on TNF- $\alpha$-induced cytotoxicity in SK-Hep- 1 cells. Toxicol In Vitro 2012;26:783-90. doi: 10.1016/j.tiv.2012.05.013.

14. Justina WC, Glenn M, Nelson F. Establishment and characterization of differentiated nontransformed hepatocyte cell lines derived from mice transgenic for transforming growth factor $\alpha$. Proceedings of the National Academy of Sciences 1993;91:674-8.

15. Ashraf NU, Sheikh TA. Endoplasmic reticulum stress and Oxidative stress in the pathogenesis of Non-alcoholic fatty liver disease. Free Radic Res 2015;49:1405-18. doi: 10.3109/10715762.2015.1078461.

16. Moravcova A, Červinková Z, Kučera O, et al. The effect of oleic and palmitic acid on induction of steatosis and cytotoxicity on rat hepatocytes in primary culture. Physiol Res 2015;64 Suppl 5:S627-36.

17. Takaki A, Kawai D, Yamamoto K. Molecular mechanisms and new treatment strategies for non-alcoholic steatohepatitis
(NASH). Int J Mol Sci 2014;29;15:7352-79. doi: 10.3390/ ijms 15057352 .

18. Szegezdi E, Logue SE, Gorman AM, et al. Mediators of endoplasmic reticulum stress-induced apoptosis. EMBO Rep 2006;7:880-5.

19. Gu X, Li K, Laybutt DR, et al. Bip overexpression, but not CHOP inhibition, attenuates fatty-acid-induced endoplasmic reticulum stress and apoptosis in HepG2 liver cells. Life Sci 2010;87:724-32. doi: 10.1016/j.1fs.2010.10.012.

20. Kammoun HL, Chabanon H, Hainault I, et al. GRP78 expression inhibits insulin and ER stress-induced SREBP-1c activation and reduces hepatic steatosis in mice. J Clin Invest 2009;119:1201-15. doi: 10.1172/JCI37007.

21. Dara L, Ji C, Kaplowitz N. The contribution of endoplasmic reticulum stress to liver diseases. Hepatology 2011;53:175263. doi: 10.1002/hep. 24279 .

22. Zhang K, Wang S, Malhotra J, et al. The unfolded protein response transducer IRE1 $\alpha$ prevents ER stress-induced hepatic steatosis. EMBO J 2011;30:1357-75. doi: 10.1038/ emboj.2011.52. 